\title{
Preliminary assessment of nocturnal bird migration at the Bay of Biscay as observed by moon-watching.
}

Nadja Weisshaupt ${ }^{1 *}$, Mercedes Maruri $^{2,3,4}$, Juan Arizaga ${ }^{1}$

\begin{abstract}
The East-Atlantic flyway represents one of the main bird migration routes worldwide, in which the Bay of Biscay acts as a geographic barrier. So far, the significance of the Bay of Biscay for migrants and its impact on their routes has not received a great deal of attention. The main goal of this study is to characterize the composition of nocturnal bird migration along the coast of the Bay of Biscay in northern Iberia. For this purpose, moon-watching was carried out at two study sites (Punta Galea, Cape Higuer) during spring and autumn 2014. The vast majority of observed migrants consisted of singly flying passerines, with a number of interspersed groups of non-passerines such as waterfowl, waders and swifts.
\end{abstract}

Key words: East-Atlantic flyway, Basque coast, passerines, spring and autumn migration.

\section{Resumen}

La ruta del Atlántico Oriental es una de las rutas de vuelo migratorio mas importantes en el mundo e incluye el golfo de Vizcaya como barrera geográfica. La importancia y el impacto del golfo de Vizcaya para las aves migratorias y sus rutas no han recibido mucha atención en la investigación. El objetivo principal de este estudio es caracterizar el ensamblaje de las aves que migran de noche por la zona del golfo de Vizcaya en el norte de la Península Ibérica.

\footnotetext{
1 Society of Sciences Aranzadi. Department of Ornithology. Zorroagagaina 11 • E-20014 Donostia-S. Sebastián, Spain

2 Institute for Applied Mathematics, University of the Basque Country, Spain.

3 Basque Meteorology Agency (Euskalmet), Alava, Spain.

4 TECNALIA-Energy and Environment Division-Meteo Area, Miñano, Alava, Spain.
} 
Para ello, se han efectuado observaciones lunares en dos sitios de muestreo (Punta Galea, Cabo de Higer) en primavera y otoño 2014. La mayoría de las aves registradas eran paseriformes volando individualmente, y algunos grupos de no-paseriformes como aves acuáticas, limícolas o vencejos.

Palabras clave: la ruta migratoria del Atlántico, costa vasca, paseriformes, migracion prenupcial y posnupcial.

\section{Laburpena}

Atlantiko ekialdeko ibilbidea munduko migrazio bide garrantzitsuenetako bat da eta horretan Bizkaiko golkoa barrera geografikoa dago. Bizkaiko golkoak hegazti migratzaileentzat eta horien ibilbidean zer garrantzi eta eragin duen ez da askorik ikertu. Bada, ikerlan honen helburu nagusia da Iberiar penintsulako iparraldean, Bizkaiko golkoko eremutik gauez migratzen duten hegaztien multzokatze ezaugarriak jakitea. Horretarako behaketak egin dira ilargi beteko aldietan bi laginketa puntutan (Galea eta Higer lurmuturrak), 2014ko udaberrian eta udazkenean. Erregistratutako hegazti gehienak paseriformeak ziren, banaka hegaz; baina bai talde ez-paseriforme batzuk ere, hegazti urtarrak, zangaluzeak edo sorbeltzak, kasu.

Gako hitzak: Atlantic flyway, Basque coast, passerines, spring and autumn migration.

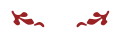

Studying active nocturnal bird migration entails various challenges, such as reduced (or no) visibility, and requires appropriate measuring techniques. One technique to quantify this type of migration is moon-watching, probably the oldest of all as it was applied already in the 19th century (e.g. Scott 1881, Chapman 1888 and Libby 1889 in Lowery 1951). Birds passing in front of the lunar disc are observed and counted through a telescope. Depending on the flight and silhouette characteristics, it is possible to identify bird families, but practically no species (Liechti et al. 1996). Even though very simple to implement, data collection by moon-watching is restricted to a few cloudless nights around full moon. This method is described in detail by Lowery (1951) and has been widely used in various studies, also in more recent times [e.g. Kiepenheuer and Linsenmair (1965), Nisbet and Drury (1969), Liechti et al. (1995), Liechti 2001].

Bird migration studies along the coast of the Bay of Biscay have focused on ringing data from landed migrants mainly from autumn campaigns, or also on daytime observations of active migration (e.g. Lack and Lack 1953, Grandio and Belzunce 1987, Mendiburu et al. 2009, Arizaga et al. 2014). Thus spring data per se and overall knowledge on active nocturnal migration is scarce. The aim of this note is to contribute to the characterization of nocturnal bird migration, and in particular bird assemblage, along the coast of the southeastern Bay of Biscay (northern Iberia), based on preliminary results obtained from a moon-watching study. 
To gain more information on the nocturnal migrant composition, moon-watching was carried out at two study sites on the Basque coast: Punta Galea, Bilbao $\left(43^{\circ} 22^{\prime} \mathrm{N}, 03^{\circ} 02^{\prime} \mathrm{W}\right)$ in the west, and Cape Higuer, Hondarribia $\left(43^{\circ} 23^{\prime} \mathrm{N}, 01^{\circ} 47^{\prime} \mathrm{W}\right)$ in the east, close to the French border. If cloud cover allowed, two nights prior to until two nights after full moon (sensu Lowery 1951) were sampled from March to May 2014 at Punta Galea, and in September 2014 at both study sites (no simultaneous observations). A telescope (Swarosvki ATS 65 HD, Zoom 20-60x) and a digital camera (Canon, Power Shot SX220 HS) were used to "videoscope" (video recording through telescope) the lunar disc to facilitate posterior analysis. Like this, each suitable night yielded samples of 30-60 min. The sampling time per night was restricted by the battery life of the camera and the limited personnel on site (1 person), as well as by meteorological conditions (clouds in front of the lunar disk). However, as the lunar samples should serve as a complementary measurement of bird composition (no bird flux or directions) for a simultaneous thermal-imaging study only, the sampling effort was not extended, but rather adapted to what was observed in the thermal-imaging camera at the same site, i.e. if the camera recorded no activity, no moon-watching was performed (e.g. in particular in May). Passing birds were counted and assigned to the categories passerines vs. non-passerines or, if possible, also down to family levels, e.g. larids, swifts, thrushes, etc. Migration traffic rates or directional calculations as detailed in Lowery (1951) were not targeted in this study, still a descriptive account of migrants flow is provided.

In spring 2014, overall $4.8 \mathrm{~h}$ of moon-watching were recorded in 4 nights in March (2:53 h), 3 nights in April (1:42 h) and 1 night in May (00:15 h) at Punta Galea. 66 (88\%) birds were identified as passerines, apparently thrushes or thrush-like species, and 9 (12\%) were ducks. We observed decreasing migration intensity in the course of spring, with a mean flow of 22.2 birds/h in March, 1.5 birds/h in April, and 0 birds/h in May. Further occasional unrecorded observations included also a small flock of four waders. In autumn, overall 35 birds were recorded in 2.25 h: 34 birds in 2 nights at Cape Higuer, equivalent to 1.8 h, and one night at Punta Galea with one bird, equivalent to 0.5 h of recordings. 32 (94\%) migrants at Cape Higuer were singly flying passerines with some swifts interspersed; the remaining 2 (6\%) were larids (gulls or terns). Mean flow was 19.31 birds/h. At Punta Galea, in contrast to spring observations (especially in March), autumn migration was nearly zero and only one gull/tern was observed, i.e. the mean flow was 2 birds/h.

Moon-watching provided data allowing us to have an overview over migrants'assemblage in the southeastern Bay of Biscay. The vast majority of these birds consisted of singly flying passerines, with some interspersed groups of non-passerines such as waterfowl, waders or swifts. A short moon-watching sequence is available at http://www.aranzadi.eus/fileadmin/videos/Moonwatch_Videoteil_kuerzer2.avi which was recorded on March 13, 2014, at Punta Galea, (Spain), showing two single passerines (00:15 and 00:17) and 9 ducks (00:28). The predominance of passerines is in line with findings based on radar and moon-watching from nearby regions such as the western Mediterranean or southern England (e.g. Parslow 1968, Liechti et al. 1995). Interestingly, 
migration activity at Punta Galea seemed to be higher in spring than in autumn. Overall, the effort of this exploratory study, which principally targeted bird composition, is insufficient to deduce any further migratory patterns like directions and migration intensity (i.e. "migration traffic rates" sensu Liechti et al. 1995). In order to obtain such migration parameters, which allow for comparisons with data from other areas, and to draw any robust conclusions on a potential seasonal variability, a more ample moonwatching study would be needed, i.e. standardized simultaneous observations as detailed in Lowery (1951) and Liechti et al. (1995), at various sites along the Bay of Biscay, in both spring and autumn. Ideally, such a study should include observations in clear skies of at least 30 minutes per night, once the moon has risen up to at least $14^{\circ}$ above the horizon (if the moon is lying lower, directional and quantitative estimations become inaccurate) (Nisbet 1959). However, given the highly variable meteorological conditions prevailing at the Bay of Biscay, which also reduced and affected the presented effort in the field considerably, other sampling methods with less limited sampling requirements (not only during full moon and in clear skies), such as radar or thermal imaging, could be worthy alternatives for further nocturnal studies in the area.

\section{Acknowledgements}

This research was partly funded by the Basque Government and the Gipuzkoa Administration. Sampling at Cape Higuer was facilitated by the Camping Faro de Higuer.

\section{Bibliography}

- Arizaga, J., Fontanilles, P., Laso, M., Andueza, M., Unamuno, E., Azkona, A. et al. 2014. Stopover by reed-associated warblers Acrocephalus spp. in wetlands in the southeast of the Bay of Biscay during the autumn and spring passage. Rev. Catalana d'Ornitología 30: 13-23.

- Kiepenheuer, J., Linsenmair, K.E. 1965. Vogelzug an der nordafrikanischen Küste von Tunesien bis Rotes Meer. Vogelwarte 23: 80-94.

- Lack, D., Lack, E. 1953. Visible migration through the Pyrenees: an autumn reconnaissance. Ibis 95: 271-309.

- Liechti, F. 2001. Calibrating the moonwatching method - chances and limits. Avian Ecol. Behav. 7: $27-40$.

- Liechti, F., Bruderer, B., Paproth, H. 1995. Quantification of nocturnal bird migration by moonwatching: comparison with radar and infrared observations. J. Field Ornithology 66(4): 457-468.

- Liechti, F., Peter, D., Lardelli, R., Bruderer, B. 1996. Herbstlicher Vogelzug im Alpenraum nach Mondbeobachtungen - Topographie und Wind beeinflussen den Zugverlauf. Ornithologischer Beobachter 93: 131-152. 
- Lowery, G.H. 1951. A quantitative study of the nocturnal migration of birds. Univ. Kansas Publ., Mus. Nat. Hist. 3: 361-472.

- Mendiburu, A., Aranguren, I., Elosegi, Z., Jauregi, J.I., Sánchez, J.M., Cuadrado, J.F. et al. 2009. Resultados de la primera campaña de anillamiento en el paso migratorio posnupcial en la vega de la regata de Jaizubia (marismas de Txingudi). Rev. Anill. 23: 26-34.

- Nisbet, I.C.T. 1959. Calculation of Flight Directions of Birds Observed Crossing the Face of the Moon. Wilson Bull. 71(3): 237-243.

- Nisbet, I.C.T., Drury, Jr W.H. 1969. A migration wave observed by moon-watching and at banding stations. Bird-Banding 40: 243-252.

- Parslow, J.L.F. 1969. The migration of passerine night migrants across the English Channel studied by radar. Ibis 111: 48-79. 